\title{
Interaction between litter quality and simulated water depths on decomposition of two emergent macrophytes
}

\author{
Yajun XIE,${ }^{1,2}$ Yonghong XIE,$^{*}$ Cong HU,${ }^{1,2}$ Xinsheng CHEN,${ }^{1}$ Feng LI ${ }^{1}$ \\ ${ }^{1}$ Dongting Lake Station for Wetland Ecosystem Research, Key Laboratory of Agro-ecological Processes in Subtropical Regions, Institute \\ of Subtropical Agriculture, The Chinese Academy of Sciences, Hunan 410125, China; ${ }^{2}$ University of Chinese Academy of Sciences, \\ Beijing 00049, China \\ *Corresponding author: yonghongxie@163.com
}

\begin{abstract}
Both water depth and litter quality are important factors influencing litter decomposition in wetlands, but the interactive role of these factors in regulating mass loss and nutrient dynamics is far from clear. The responses of mass loss and nutrient dynamics to simulated water depths and litter quality are investigated in leaves of Carex brevicuspis and leaves and stems of Miscanthus sacchariflorus from the Dongting Lake, China. Three litter types differing in litter quality were incubated for 210 days at three water depths $(0 \mathrm{~cm}, 5$ $\mathrm{cm}$, and $80 \mathrm{~cm}$, relative to the water surface) in a pond near the Dongting Lake. The litter mass remaining, nitrogen (N), phosphorus $(P)$, organic carbon (organic C), cellulose, and lignin contents were analyzed during the controlled decomposition experiment. Moreover, water properties (temperature, dissolved oxygen content, and conductivity) and fungal biomass were also characterized. Initial $N$ and $P$ contents were highest in $\mathrm{C}$. brevicuspis leaves, intermediate in $\mathrm{M}$. sacchariflorus leaves and lowest in $\mathrm{M}$. sacchariflorus stems, whereas the organic C, cellulose, and lignin contents exhibited an opposite trend. After a 210 days incubation, decomposition rate was highest in M. sacchariflorus leaves (0.0034-0.0090 $\mathrm{g} \mathrm{g}^{-1} \mathrm{DW}$ day $\mathrm{y}^{-1}$, in exponential decay model), intermediate in $\mathrm{C}$. brevicuspis leaves (0.0019$\left.0.0041 \mathrm{~g} \mathrm{~g}^{-1} \mathrm{DW} d a y^{-1}\right)$, and lowest in $\mathrm{M}$. sacchariflorus stems (0.0005-0.0011 $\mathrm{g} \mathrm{g}^{-1} \mathrm{DW}$ day $\left.\mathrm{y}^{-1}\right)$. Decomposition rate of $\mathrm{C}$. brevicuspis leaves was highest at $5 \mathrm{~cm}$ water depth, intermediate at $80 \mathrm{~cm}$, and lowest at $0 \mathrm{~cm}$. Decomposition rate of M. sacchariflorus leaves was higher at $5 \mathrm{~cm}$, and $80 \mathrm{~cm}$ than at $0 \mathrm{~cm}$ water depths. Water depth had no effect on decomposition of M. sacchariflorus stems. At the end of incubation, $N$ and $P$ mineralization was completely in leaf litters with increasing rates along with increasing water depth, while nutrients were accumulated in M. sacchariflorus stem. Organic C, cellulose, and lignin decayed quickly in both leaf litters compared to the stem litter. The fungal biomass was higher in leaf than in stem litters and changed as a response to water depth in both leaflitters rather than stem ones. These data indicate that submergence has no effect on the decomposition of refractory stem litter and shallower submergence stimulates degradation of the labile leaf litter.
\end{abstract}

Key words: Litter decomposition; water depth; Dongting Lake; wetland macrophytes; Carex brevicuspis; Miscanthus sacchariflorus.

Received: October 2014. Accepted: July 2015.

\section{INTRODUCTION}

Decomposition is a fundamental process influencing material cycling (i.e., carbon and nutrients) and energy flux in an ecosystem (Hoorens et al., 2003). Decomposition promotes nutrient return from plant litter to soil or water, which directly determines nutrient availability for plant growth (Guo et al., 2008). Limitations to decomposition include litter quality (i.e., nutrient, lignin content, and toughness) as well as physical-chemical conditions of the medium in which the material decomposes (Newell, 2003; Ferreira and Chauvet, 2011; Fonseca et al., 2013). Litter with a higher nutrient and a lower lignin contents usually decays quickly and easily (Fonseca et al., 2013). Water level fluctuations are common phenomena in wetlands, which determine plant growth and zonation (Drew, 1997). Water depth often results in variation of physicochemical conditions, which in turn regulates the decomposition processes of macrophyte litter (Laiho, 2006). In shallow water environments, litter decomposition is rapid due to a faster rate of leaching of dissolved organic matter and increased activities of microbes (Wallis and Raulings, 2011). In deep water ecosystems, both temperature and dissolved oxygen content are usually low limiting litter decomposition as an effect of reduced microbial activity (Torremorell and Gantes, 2010; Fonseca et al., 2013). Though many direct measurements of macrophyte decomposition rates in response to increase water depth have shown positive effects on decomposition process and nutrient release efficiency, also neutral or even negative results were reported (Cai et al., 2006; Wright et al., 2013; Arroita et al., 2015). The inconsistent effects of water depth on litter decomposition may be caused by differences in litter quality, since litter tissues (including roots, leaves, twigs and stems) used in the above-mentioned experiments differed in quality and type (Trinder et al., 2008). Refractory litters might be less sensitive to particular environmental conditions (i.e., soil fertility and tem- 
perature) than the labile ones (Sariyildiz and Anderson, 2003; Fierer et al., 2005), indicating that neutral effects might happen in presence of refractory litter, whereas positive or negative effects in presence of labile one. Therefore, these inconsistent effects might also result from interaction between water depth and litter quality.

In this study, the decomposition rate, the nutrient dynamics and the fungal biomass were investigated in a pond close to the Dongting Lake (China) using three litter types as a response to a simulated water-depth gradient (0 $\mathrm{cm}, 5 \mathrm{~cm}$, and $80 \mathrm{~cm}$, relative to the water surface) in a 210-day long controlled experiment. The litter types include Carex brevicuspis leaves [high nitrogen $(\mathrm{N})$ and phosphorus (P) contents, low lignin content], Miscanthus sacchariflorus leaves (intermediate N, P and lignin contents) and stems (low $\mathrm{N}$ and $\mathrm{P}$ contents, high lignin content). In our preliminary analyses, 5 and $80 \mathrm{~cm}$ depth environments were significant different in water physicochemical conditions including temperature, dissolved oxygen content, and conductivity) and could represent shallower and deeper submergence, respectively (according to Wrubleski et al., 1997). Both the macrophytes in analysis are dominant species in the shorelines of the Dongting Lake, that is the second largest lake in China.

Here, we tested the following hypotheses. First, decomposition would be faster in both leaf litters than in stem litter due to litter quality. Second, for leaf litters, decomposition would be stimulated at $5 \mathrm{~cm}$ and $80 \mathrm{~cm}$ depths and the effect was more significant at $5 \mathrm{~cm}$ than at $80 \mathrm{~cm}$ depth. Third, the decomposition rates of stem litter would be insensitive to water depths.

\section{METHODS}

\section{Litter materials}

Leaf litter from C. brevicuspis and leaf and stem litters from M. sacchariflorus were collected as standing dead litter from the Dongting Lake $\left(29^{\circ} 27^{\prime} 2.02^{\prime \prime} \mathrm{N}\right.$, $112^{\circ} 47^{\prime} 32.28^{\prime \prime}$ E) in November 2012. Only newly senescent brown leaf litter and standing stem litter were selected. After collection, all litters were air-dried for $48 \mathrm{~h}$ to achieve a constant mass and cut into about $10 \mathrm{~cm}$ long pieces prior to litterbag construction. Weighed litter samples $(5 \mathrm{~g})$ were placed into $10 \times 15 \mathrm{~cm}$ nylon bags. The bag mesh size was $1 \mathrm{~mm}$, which is sufficient to prevent macroinvertebrates from passing through while allowing for colonization of microbial organisms and litter fragment loss into the water (Langhans et al., 2008).

\section{Experimental set-up}

To assess the influence of water depth on decomposition rate, each litter type was randomly treated at three water depths: $0 \mathrm{~cm}, 5 \mathrm{~cm}$, and $80 \mathrm{~cm}$ water depths (relative to the water surface). All nylon bags were placed in three plastic trays $(100 \times 100 \times 10 \mathrm{~cm})$, each plastic tray containing a 6-cm washed silica sand to fasten nylon bags. A total of 54 litter bags were placed in each tray. The litter bags were randomly buried to $5 \mathrm{~cm}$ in the sand, $5 \mathrm{~cm}$ apart from each other. On January 13, 2013, the trays were gently placed in a pond near the Dongting Lake. For the $0 \mathrm{~cm}$ treatment, the sand in tray was wetted with pond water completely but with no surface pooling. For the $5 \mathrm{~cm}$ and $80 \mathrm{~cm}$ treatments, the trays were emerged at $5 \mathrm{~cm}$ and 80 $\mathrm{cm}$ depth above the sand surface, respectively (Wright et al., 2013). Water depths in the trays were adjusted weekly. The experimental pond $(800 \mathrm{~m} 2)$ was fed almost exclusively by rainfall and thus water was poor in nutrients. Total organic carbon (organic C), total N, P and K were 41.0, 1.10, 0.04 and $3.1 \mathrm{mg} \mathrm{L}^{-1}$, respectively. Other water properties (temperature, dissolved oxygen content, and conductivity) at $5 \mathrm{~cm}$ and $80 \mathrm{~cm}$ water depths were recorded with a sensION156 hand-operated electrochemistry analyzer (HACH Corporation; Loveland, CO, USA) on the first day of incubation and at each sampling day.

\section{Harvest and chemical analysis}

Three bags for each litter type and water depth were randomly sampled at day $11,30,60,90$, and 210 from the start of incubation. Simultaneously, another 9 samples (3 replicates for the 3 litter types in analysis) were sampled to measure ergosterol content at each harvest day. After collection, litter samples were hand-washed gently with deionized water until the water became transparent, then oven-dried to constant weight for a week at $60^{\circ} \mathrm{C}$ to measure the remaining dry mass (with $0.01 \mathrm{~g}$ accuracy). The samples were ground to powder and passed through a 0.5 $\mathrm{mm}$ mesh screen to analyze litter quality. Organic $\mathrm{C}$ content was analyzed using the $\mathrm{H} 2 \mathrm{SO} 4-\mathrm{K} 2 \mathrm{Cr} 2 \mathrm{O} 7$ heat method, $\mathrm{N}$ and $\mathrm{P}$ contents using Kjeldahl digestion followed by colorimetric analysis, and cellulose and lignin contents using hydrolysis of $\mathrm{H} 2 \mathrm{SO} 4$ followed by $\mathrm{Na} 2 \mathrm{~S} 2 \mathrm{O} 3$ titration (Graça et al., 2005). Initial litter qualities were determined by colorimetric analysis as described above. Fungus, especially aquatic hyphomycetes, play a fundamental role in litter decomposition in aquatic environments, and the activities of decomposer can be indicated by the fungal biomass by measuring ergosterol content (Ferreira and Chauvet, 2011). The decomposed litter samples were frozen at $-30^{\circ} \mathrm{C}$ after sampling. Ergosterol content was determined by high-performance liquid chromatography (Graça et al., 2005). For analyses, the litter material was lyophilised and ground. The extraction was done in alkaline methanol at $80^{\circ} \mathrm{C}$. Solid-phase extraction through $\mathrm{C} 18$ cartridges was used for purification. Dry, unprocessed litters were used for blank values. This material was stored dry at room temperature. In addition to ergosterol concentration, we calculated the fungal biomass at the peak time with the conversion factor of 5.5 
mg ergosterol $\mathrm{g}^{-1}$ fungal biomass, and values were expressed as $\mathrm{mg} \mathrm{g}^{-1}$ dry weight (DW).

\section{Data analysis and statistics}

The decomposition rate $(k)$ was calculated using the following equation:

$-k t=\ln (W t / W 0)$

where:

$W 0$ is the initial litter mass;

$W t$ is the mass remaining at time $\mathrm{t}$ (days) (Olson, 1963).

The remaining mass was calculated as the percentage of the initial mass, and the remaining litter components $(\mathrm{N}, \mathrm{P}$, organic $\mathrm{C}$, cellulose, and lignin) as the litter mass $\times$ litter components content. Decomposition rate, remaining mass, and remaining litter components were compared among the three litter types by three-way analysis of variance (ANOVA), with litter type, water depth, and time as the main factor. Values were log-transformed to homogenize the variances among groups. Within each litter type, the response variables were compared using two-way ANOVA with water depth and time as the main factors to test the treatment effect. Fungal biomass was compared by two-way ANOVA, with litter type and water depth as the main factor. The difference between initial litter quality and mass remaining (including dry mass, N, P, organic $\mathrm{C}$, cellulose, and lignin) of the three litter types was evaluated by LSD at the 0.05 significance level. All statistical analyses were performed using the statistical software SPSS 21 (Sun et al., 2012).

\section{RESULTS}

\section{Initial litter quality and water properties}

One-way ANOVA showed the initial N ( $F=109.4$,
$\mathrm{P}<0.01), \mathrm{P}(\mathrm{F}=47.3, \mathrm{P}<0.01)$, organic $\mathrm{C}(\mathrm{F}=38.5, \mathrm{P}<0.01)$, cellulose $(\mathrm{F}=7.0, \mathrm{P}<0.05)$, and lignin $(\mathrm{F}=14.9, \mathrm{P}<0.05)$ contents differed among the three litter types (Tab. 1). N and $\mathrm{P}$ contents were highest in C. brevicuspis leaves, intermediate in $M$. sacchariflorus leaves, and lowest in $M$. sacchariflorus stems $(\mathrm{F}=20.3, \mathrm{P}<0.05)$, whereas the organic $\mathrm{C}$, cellulose, and lignin contents ranked in the opposite order among the three litter types $(\mathrm{F}=22.6, \mathrm{P}<0.05)$. The ratios of C:N, C:P, and lignin: $\mathrm{N}$ were lowest in $C$. brevicuspis leaves, intermediate in $M$. sacchariflorus leaves, and highest in M. sacchariflorus stems. These results demonstrated that decomposition potential was highest in C. brevicuspis leaves, intermediate in $M$. sacchariflorus leaves, and lowest in M. sacchariflorus stems (Tab. 1). The Student's $t$-test showed that the temperature and dissolved oxygen content in water were significantly higher at $5 \mathrm{~cm}$ than at $80 \mathrm{~cm}$ depth, while water conductivity was significantly higher at $80 \mathrm{~cm}$ than at 0 cm depth (Fig. 1) $(\mathrm{F}=3.2, \mathrm{P}<0.05)$.

\section{Dynamics of mass remaining}

Mass remaining of the three litter types decreased slowly within the initial 90-day incubation, and then increased gradually. Decomposition rates differed with litter type $(\mathrm{F}=89.6, \mathrm{P}<0.01)$ and water depth $(\mathrm{F}=22.7, \mathrm{P}<0.01)$ (Tab. 2). At the same water depth, the decomposition rate in the three litter types decreased in the order M. sacchariflorus leaves $\left(0.0062 \mathrm{~g} \mathrm{~g}^{-1} \mathrm{DW}\right.$ day $\left.^{-1}\right)>C$. brevicuspis leaves $\left(0.0030 \mathrm{~g} \mathrm{~g}^{-1} \mathrm{DW}\right.$ day $\left.^{-1}\right)>M$. sacchariflorus stems $\left(0.0008 \mathrm{~g} \mathrm{~g}^{-1} \mathrm{DW}\right.$ day $\left.{ }^{-1}\right)$. Decomposition was fastest in M. sacchariflorus leaves at $5 \mathrm{~cm}$ depth $\left(0.0087 \mathrm{~g} \mathrm{~g}^{-1} \mathrm{DW}\right.$ day $^{-1}$ ), and slowest in $M$. sacchariflorus stems at $80 \mathrm{~cm}$ depth $\left(0.0006 \mathrm{~g} \mathrm{~g}^{-1}\right.$ DW day $\left.{ }^{-1}\right)$.

Two-way ANOVAs showed a significant interaction between litter type and water depth, indicating that the effect of water depth differed among the three litter types

Tab. 1. Initial nitrogen $(\mathrm{N})$, phosphorus $(\mathrm{P})$, organic carbon (Organic C), cellulose, lignin contents, ratios of C:N, C:P, N:P, and lignin: $\mathrm{N}$ of three types of litters.

\begin{tabular}{lccc} 
Parameter & Litter type & M. sacchariflorus stem \\
$\mathrm{N}\left(\mathrm{mg} \mathrm{g}^{-1}\right)$ & $7.68 \pm 0.18^{\mathrm{a}}$ & M. sacchariflorus leaves & $1.40 \pm 0.25 \mathrm{c}$ \\
$\mathrm{P}\left(\mathrm{mg} \mathrm{g}^{-1}\right)$ & $0.89 \pm 0.10^{\mathrm{a}}$ & $4.15 \pm 0.85^{\mathrm{b}}$ & $0.14 \pm 0.02 \mathrm{c}$ \\
\hline Organic C (\%) & $38.37 \pm 1.77^{\mathrm{c}}$ & $0.48 \pm 0.13^{\mathrm{b}}$ & $49.12 \pm 1.70^{\mathrm{a}}$ \\
Cellulose (\%) & $14.61 \pm 0.31^{\mathrm{a}}$ & $13.13 \pm 0.85^{\mathrm{b}}$ & $18.48 \pm 0.14^{\mathrm{c}}$ \\
\hline Lignin (\%) & $30.75 \pm 1.41^{\mathrm{a}}$ & $32.42 \pm 0.91^{\mathrm{b}}$ & $34.47 \pm 2.64^{\mathrm{c}}$ \\
C:N & $50.02 \pm 3.26^{\mathrm{a}}$ & $107.73 \pm 27.30^{\mathrm{b}}$ & $359.86 \pm 83.73^{\mathrm{c}}$ \\
\hline C:P & $433.87 \pm 27.85^{\mathrm{a}}$ & $943.47 \pm 230.72^{\mathrm{b}}$ & $3534.33 \pm 605.00^{\mathrm{c}}$ \\
$\mathrm{N}: \mathrm{P}$ & $8.72 \pm 1.09^{\mathrm{b}}$ & $8.87 \pm 1.94^{\mathrm{a}}$ & $9.97 \pm 1.67^{\mathrm{c}}$ \\
\hline Lignin:N & $40.07 \pm 2.09^{\mathrm{a}}$ & $80.99 \pm 20.76^{\mathrm{b}}$ & $253.04 \pm 63.35^{\mathrm{c}}$
\end{tabular}

Values are means \pm standard deviation, are expressed on a dry mass basis, and are means of three replicates. ${ }^{a, b, c}$ Different letters indicate a significant difference in initial leaf chemistry among the three litter types; the differences were compared by least significant deviation at the 0.05 significance level. 
$(\mathrm{F}=9.7, \mathrm{P}<0.01$ ) (Fig. 2). Decomposition rates were only affected by water depth $(\mathrm{F}=29.9, \mathrm{P}<0.01)$ in both leaf litters rather than stem litter, ranked in the following order: $5 \mathrm{~cm} \geq 80 \mathrm{~cm}>0 \mathrm{~cm}$.

\section{Dynamics of litter chemical components}

At the same water depth, the litter $\mathrm{N}$ and $\mathrm{P}$ contents of the three litter types increased in the order M. sacchariflorus stems $<M$. sacchariflorus leaves $<C$. brevicuspis leaves, while the order for litter $\mathrm{C}$, lignin, and cellulose contents was: $M$. sacchariflorus leaves $<C$. brevicuspis leaves $<M$. sacchariflorus stems (Fig. 3). Both leaf litters released $\mathrm{N}$ and $\mathrm{P}$ at the end of incubation, while $M$. sacchariflorus stems showed an accumulation of these nutrients. Similar to the mass loss, litter C, cellulose, and lignin were released slowly in $M$. sacchariflorus stems $(\mathrm{F}=35.9$, $\mathrm{P}<0.01)$. Two-way ANOVAs showed that the release of $\mathrm{C}$, P, and lignin of the two leaf litters was significantly promoted by increasing water depth $(\mathrm{F}=46.9, \mathrm{P}<0.01)$. The lignin content of $M$. sacchariflorus stems was also affected by water depth $(\mathrm{F}=4.6, \mathrm{P}<0.05)$. Other litter chemical components were not affected by water depth $(\mathrm{F}=1.6, \mathrm{P}>0.05)$.

\section{Fungal biomass}

Among the three litter types, fungal biomass was higher in C. brevicuspis leaves, and lower in $M$. sacchariflorus stems $(\mathrm{F}=58.7, \mathrm{P}<0.05)$ (Fig. 4). At the end of the experiment, the fungal biomass of both leaf litters rather than stem litter was significantly affected by water depth $(\mathrm{F}=58.7, \mathrm{P}<0.01)$ (Fig. 4). Two-way ANOVAs showed a significant interaction between litter type and water depth, indicating that the effect of water depth differed among the three litter types $(\mathrm{F}=3.3, \mathrm{P}<0.05)$ (Fig. 4). Fungal biomass was only affected by water depth $(\mathrm{F}=6.9, \mathrm{P}<0.05)$ in both leaf litters rather than stem litter, ranked in the following order: $5 \mathrm{~cm} \geq 80 \mathrm{~cm}>0 \mathrm{~cm}$.

\section{DISCUSSION}

\section{Litter quality and decomposition}

At the same water depth, decomposition rates among

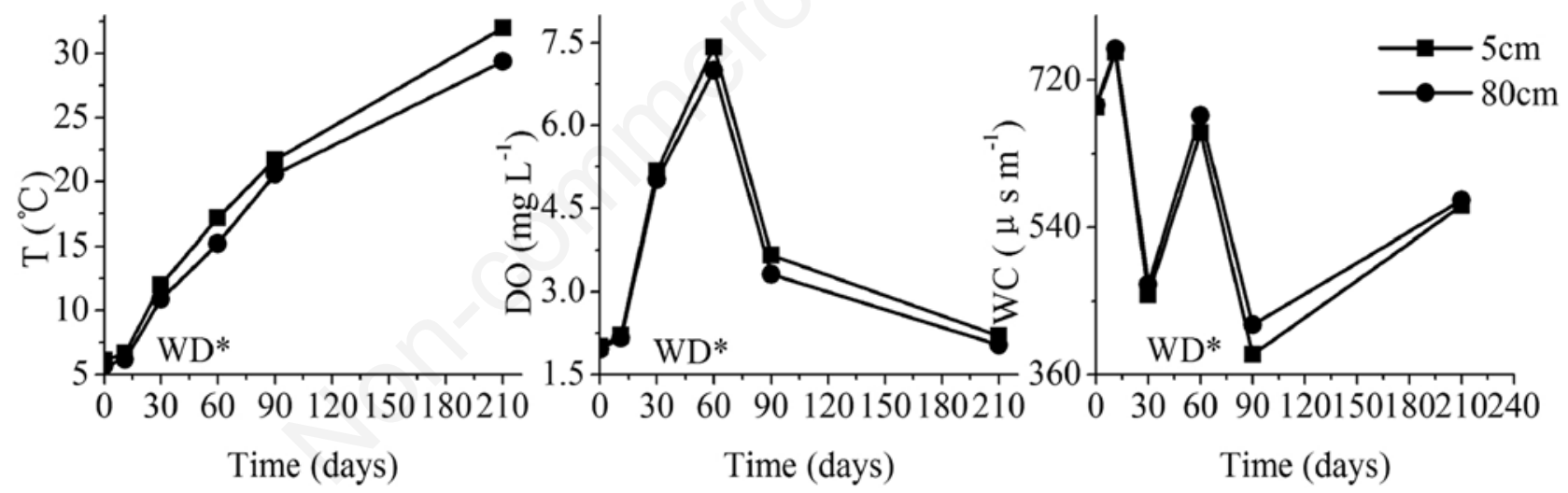

Fig. 1. Dynamics of water properties at $5 \mathrm{~cm}$ and $80 \mathrm{~cm}$ water depths (WD). ${ }^{*} \mathrm{P}<0.05$. T, temperature; DO, dissolved oxygen content; WC, water conductivity.

Tab. 2 Decomposition rates $(k)$ of three types of litters at $0 \mathrm{~cm}, 5 \mathrm{~cm}$ and $80 \mathrm{~cm}$ water depth at the end of the experiment.

\begin{tabular}{lccccc} 
& & & $k\left(\mathrm{~g} \mathrm{~g}^{-1}\right.$ dry mass day & \\
& & & & & Mean \\
Carex brevicuspis leaves & $0.0018^{\mathrm{d}}(0.009)$ & $0.0041^{\mathrm{b}}(0.0005)$ & $0.0031^{\mathrm{c}}(0.0004)$ & 0.0030 & 0.0011 \\
Miscanthus sacchariflorus leaves & $0.0036^{\mathrm{c}}(0.0006)$ & $0.0087^{\mathrm{a}}(0.0024)$ & $0.0062^{\mathrm{ab}}(0.0026)$ & 0.0062 & 0.0028 \\
\hline Miscanthus sacchariflorus stem & $0.0007^{\mathrm{e}}(0.0001)$ & $0.0010^{\mathrm{de}}(0.0005)$ & $0.0006^{\mathrm{e}}(0.0001)$ & 0.0008 & 0.0003 \\
Mean & 0.0021 & 0.0046 & 0.0033 & \\
\hline SD & 0.0014 & 0.0036 & 0.0027 & \\
\hline
\end{tabular}

Values are means \pm standard deviation, and are means of three replicates. The numbers in brackets are estimated standard deviations. a-eDifferent letters indicate a significant difference in litter decomposition rates among the three litter types; the differences were compared by least significant deviation at the 0.05 significance level. 
the three litter types decreased in the order M. sacchariflorus leaves $>C$. brevicuspis leaves $>M$. sacchariflorus stem, which is consistent with our first hypothesis. The slowest decomposition and highest $\mathrm{C}$ content in the $M$. sacchariflorus stems might reflect a $\mathrm{N}$ or $\mathrm{P}$ limitation (Freschet et al., 2012). In addition, also the lower initial $\mathrm{N}$ and $\mathrm{P}$ contents and the higher ratios of $\mathrm{C}: \mathrm{N}, \mathrm{C}: \mathrm{P}$, and lignin: $\mathrm{N}$ contribute to make the $M$. sacchariflorus stems recalcitrant to decay (Lan et al., 2006; Pettit et al., 2012). It is surprising that $C$. brevicuspis leaves with higher $\mathrm{N}$ and $\mathrm{P}$ contents decay at a lower rate than do $M$. sacchar-

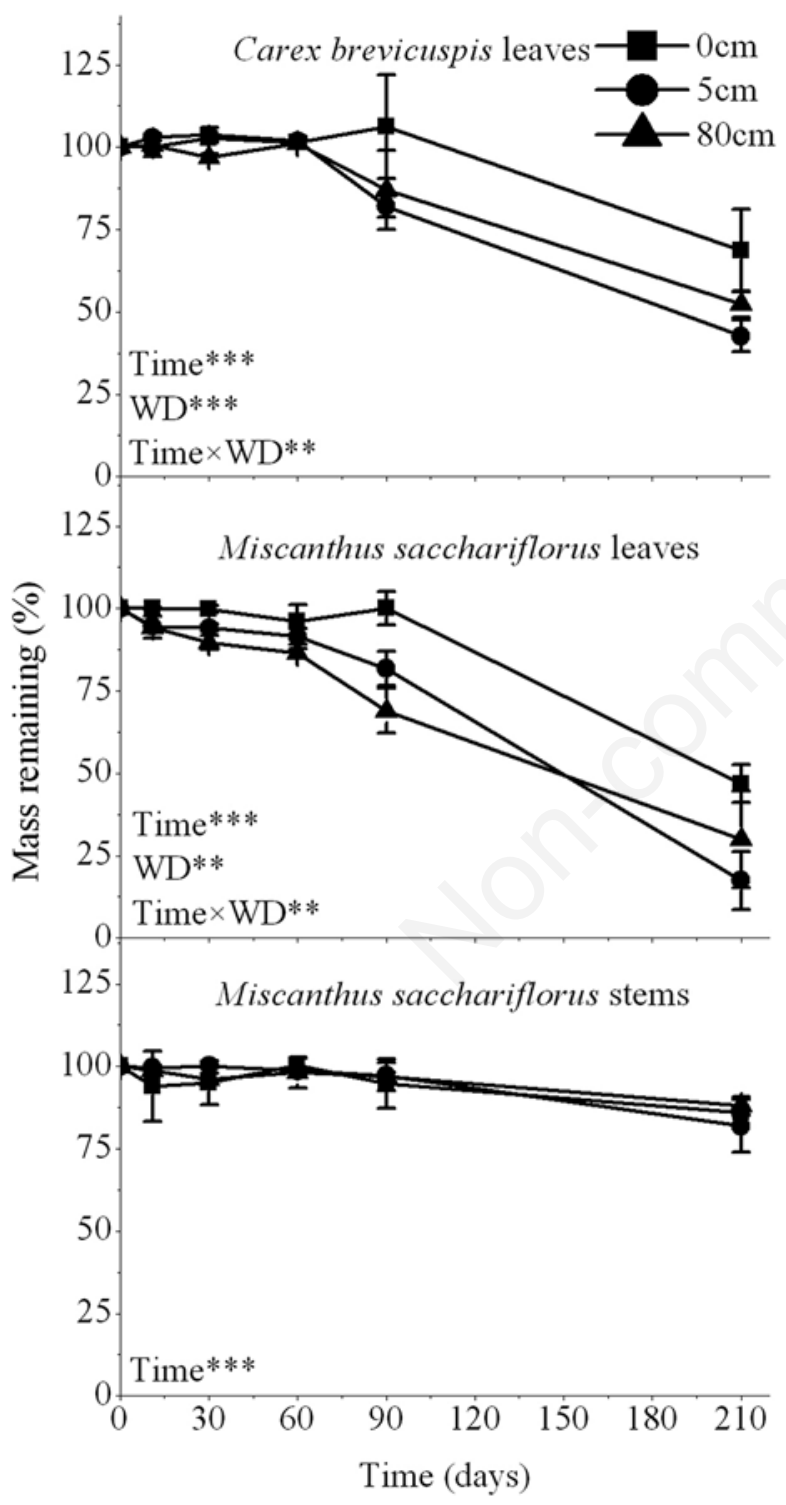

Fig. 2. Decomposition (expressed as the percentage of mass remaining respect to initial dry mass) of different litter types in response to water depth (WD) at 0,5 , and $80 \mathrm{~cm} . * \mathrm{P}<0.05$; $* * \mathrm{P}<0.01 ; * * * \mathrm{P}<0.001$. iflorus leaves with lower $\mathrm{N}$ and $\mathrm{P}$ contents. Actually, nutrient content is not the sole factor in determining decomposition rate of aquatic macrophytes (Gijsman et al., 1997). Other aspects, such as lower toughness and higher initial cellulose content, can explain the faster lignin decay observed (Moorhead and Sinsabaugh, 2006; Fonseca et al., 2013).

\section{Water depth and leaf litter decomposition}

The decomposition rates of both leaf litters among the three water depths were decreased in the order $5 \mathrm{~cm}>80$ $\mathrm{cm}>0 \mathrm{~cm}$ for C. brevicuspis leaves and $5 \mathrm{~cm} \geq 80 \mathrm{~cm} 0$ $80 \mathrm{~cm}$ for M. sacchariflorus leaves. This result is partially consistent with our second hypothesis. The decomposition rates of both leaf litters were slowest at $0 \mathrm{~cm}$, suggesting a stimulation effect by submergence in liable litters. Inhabitation or promotion by water depth have also been reported in other studies (Wallis and Raulings, 2011; Sun et al., 2012). Besides by increasing leaching and physical fragmentation resulting from submergence itself (Torremorell and Gantes, 2010; Wallis and Raulings, 2011), water depth variation might also affected litter decomposition through the decomposer. Generally, litter decomposition rate depended on the utilization rate of decomposer (Beth et al., 2012).

In this experiment, fungal biomass was affected by litter type, water depth and their interaction. Fungus must assimilate nutrients from available resources to maintain the balance in component composition (Beth et al., 2012). Both leaf litters released C, N, P and lignin during litter incubation, indicating that nutrient demands of fungus is satisfied by litter decomposition (Xie et al., 2004). However, fungal biomass of both leaf litters was higher at 5 $\mathrm{cm}$ and $80 \mathrm{~cm}$ than at $0 \mathrm{~cm}$ water depths, which might be resulted from an adaptive response of fungal growth and reproduction to adequate moisture by submergence (Wallis and Raulings, 2011; Sun et al., 2012;). The faster release of nutrients, lignin and cellulose as a response to submergence also reflected that fungus utilized litter more efficiently (Fonseca et al., 2013). As a result, we observed both leaf litters decay faster at submergence than at $0 \mathrm{~cm}$ water depth.

C. brevicuspis leaves decayed slower at $80 \mathrm{~cm}$ than at $5 \mathrm{~cm}$ water depths, implying a less stimulation at $80 \mathrm{~cm}$ water depths. This phenomenon might result from the harsher water condition at $80 \mathrm{~cm}$, including lower temperature and dissolved oxygen content and higher conductivity. In such environment, fungus might be impeded from colonization due to lower nutrients uptake ability and enzymatic activity (Battle and Golladay, 2001). Therefore, the fungal biomass was lower at $80 \mathrm{~cm}$ due to slower $\mathrm{C}, \mathrm{P}$, and lignin releases. However, both $5 \mathrm{~cm}$ and $80 \mathrm{~cm}$ water depth showed similar stimulation in the most fast-decaying litter of M. sacchariflorus leaves, indicating that the de- 
composition of some litter types was too fast to be limited by harsh environmental conditions (Gijsman et al., 1997; Straková et al., 2010). Though releases of C, P, and lignin were slower at $80 \mathrm{~cm}$ than at $5 \mathrm{~cm}$ water depths, no difference in fungal biomass was observed between them, indicating that fungus activity was not inhibited by the harsher condition at $80 \mathrm{~cm}$ water depth. Any decomposers (fungi and invertebrates) associated with the highly decomposable leaf litter would also be effective in deep water as reported by Pozo et al. (1998). Fungus could also change its functional composition, i.e. from terrestrial fungus to aquatic hyphomycetes, to adapt to hypoxic-submergence environments (Peltoniemi et al., 2012).

\section{Water depth and stem litter decomposition}

Water depth had no impact on the decomposition of M. sacchariflorus stems, suggested that decomposition of refractory litters might be primarily regulated by its poor quality and was insensitive to environmental condition variation (Fonseca et al., 2013). This is consistent with our third hypothesis. Other studies have also reported the insensitivity of refractory litters to temperature and soil fertility (Sariyildiz and Anderson, 2003; Fierer et al., 2005). One reason might result from the lower nutrient contents in stem litters. Stem litters showed immobilization in nutrients and slow releases in organic $\mathrm{C}$, lignin and cellulose, indicating that the fungus could not assimilate enough $\mathrm{N}$ and $\mathrm{P}$ from the poor-nutrients stem litter to utilize the organic C (Beth et al., 2012). Though litter decay at three water depths experienced different submergence conditions, the nutrients accumulation were unaffected by water depth. Therefore, fungal consumption of stem litter can be limited by nutrients at all water depths, as supported by the lower and unchanged fungal biomass (Ferreira and Chauvet, 2011). Another reason might result from the recalcitrant component including cellulose and lignin in stem litter. A previous study has suggested that highly recalcitrant components, such as cellulose and lignin, would make the stem more resistant to physical abrasion compared to the leaf (Fonseca et al., 2013). Our evidence suggests that the loss of cellulose and $\mathrm{C}$ of $M$. sacchariflorus stems were also unaffected by water depth. Therefore, the insensitiveness of stem decomposition to water depth might also result from its highest cellulose and $\mathrm{C}$ contents.

\section{CONCLUSIONS}

Effects of increasing water depth on macrophytes decomposition yield consistent results. This study provided quantitative support that decomposition of emergent macrophytes depended on interaction between litter quality and water depth. Submergence has no effect on the decomposition of refractory stem litter, due to litter's lower nutrients content and resistance to physical abrasion. Hence, C. brevicuspis leaves decayed slower at deeper submergence than at shallower submergence, implying a less stimulation at $80 \mathrm{~cm}$ water depths, due to the harsher water condition at deeper water. Submergence stimulates degradation of the labile leaf thanks to the fact that the nutrients demand and the activities of decomposers increase in proportion to the increase in moisture levels.

The analysis of aquatic ecosystem functions should take into account the interaction between litter quality and water depth because of their importance in biogeo-
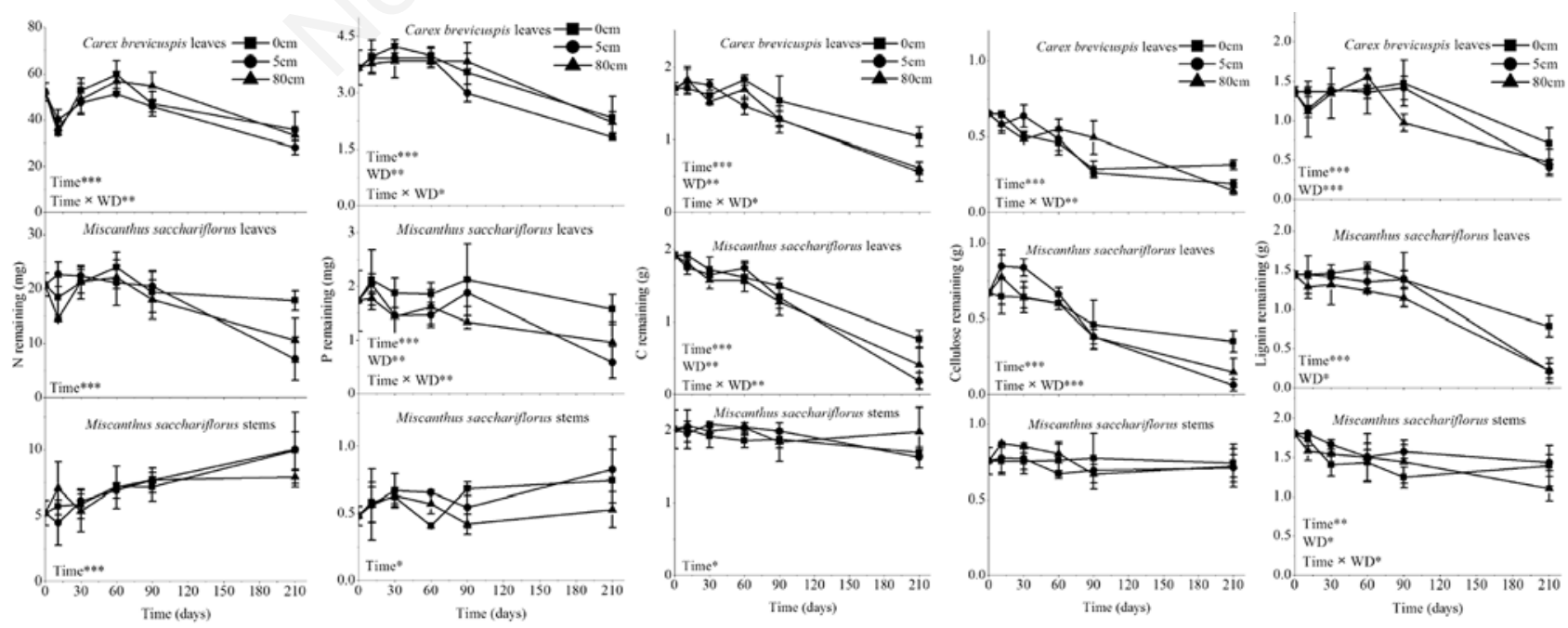

Fig. 3. Dynamics of the litter component contents on a dry mass basis at 0,5 , and $80 \mathrm{~cm}$ water depths $(\mathrm{WD})$. ${ }^{*} \mathrm{P}<0.05$; ${ }^{*} * \mathrm{P}<0.01$; $* * * \mathrm{P}<0.001$. 


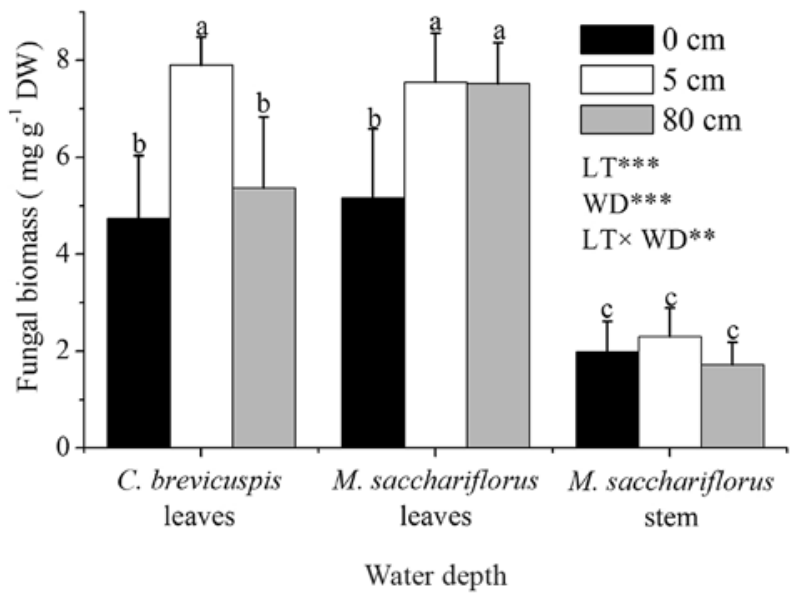

Fig. 4. Fungal biomass of three litter types (LT) at 0,5 , and 80 cm water depths (WD). ${ }^{* *} \mathrm{P}<0.01 ; * * * \mathrm{P}<0.001$. Different letters $(\mathrm{a}, \mathrm{b}, \mathrm{c})$ indicate a significant difference in fungal biomass among the three water depths.

chemical processes. The Three Gorges Project, the largest hydropower of construction scale in the world, has changed the hydrology of some lakes such as the Dognting Lake. Our study suggested that the labile litters required more attention than refractory ones in evaluation the nutrient recycle responses to hydrological changes. Given that our study was only 210 days long, and our findings are exclusively related to the early stages of decomposition and cannot predict long-term decomposition rates, we needed to further explorations of the response of litter decomposition to water depth changes in experiments of several years.

\section{ACKNOWLEDGMENTS}

This study was financially supported by the National Key Technology R \& D Program (2014BAC09B03), the National Basic Research Program of China (2012CB417000), International Science \& Technology Cooperation Program of China (2012DFB30030).

\section{REFERENCES}

Arroita M, Aristi I, Díez J, Martinez M, Oyarzun G, Elosegi A, 2015. Impact of water abstraction on storage and breakdown of coarse organic matter in mountain streams. Sci. Total. Environ. 503-504:233-240.

Battle JM, Golladay SW, 2001. Hydroperiod influence on breakdown of leaf litter in cypress-gum wetlands. Am. Midl. Nat. 146:128-145.

Cai L, Ji KF, Hyde KD, 2006. Variation between freshwater and terrestrial fungal communities on decaying bamboo culms. Anton. Leeuw. Int. J. G. 89:293-301.

Beth MC, Erika BK, Jackson RW, 2012. Immobilization and mineralization of $\mathrm{N}$ and $\mathrm{P}$ by heterotrophic microbes during leaf decomposition. Freshwater Sci. 31:133-147.

Drew MC, 1997. Oxygen deficiency and root metabolism: injury and acclimation under hypoxia and anoxia. Annu. Rev. Plant Physiol. 48:223-250.

Fierer N, Craine JM, McLauchlan K, Schimel JP, 2005. Litter quality and the temperature sensitivity of decomposition. Ecology, 86:320-326.

Ferreira V, Chauvet E, 2011. Synergistic effects of water temperature and dissolved nutrients on litter decomposition and associated fungi. Global. Change. Biol. 17:551-564.

Freschet GT, Weedon JT, Aerts R, Hal JR, Cornelissen JH, 2012. Interspecic differences in wood decay rates: insights from a new short-term method to study long-term wood decomposition. J. Ecol. 100:161-170.

Fonseca AL, Bianchini I, Pimenta CM, Soares CB, Mangiavacchi N, 2013. The flow velocity as driving force for decomposition of leaves and twigs. Hydrobiologia 703:59-67.

Gijsman AJ, Alarcón HF, Thomas RJ, 1997. Root decomposition in tropical grasses and legumes, as affected by soil texture and season. Soil. Biol. Biochem. 29:1443-1450.

Graça MA, Bälocher F, Gessner MO, 2005. Methods to study litter decomposition: a practical Guide. Springer, Dordrecht: 329 pp.

Guo XL, Lu XG, Tong SZ, Dai GH, 2008. Influence of environment and substrate quality on the decomposition of wetland plant root in the Sanjiang Plain, Northeast China. J. Environ. Sci-China 20:1445-1452.

Hoorens B, Aerts R, Stroetenga M, 2003. Does initial litter chemistry explain litter mixture effects on decomposition? Oecologia 137:578-586.

Laiho R, 2006. Decomposition in peatlands: reconciling seemingly contrasting results on the impacts of lowered water depths. Soil. Biol. Biochem. 38:2011-2024.

Lan NK, Asaeda T, Manatunge J, 2006. Decomposition of aboveground and belowground organs of wild rice (Zizania latifolia): mass loss and nutrient changes. Aquat. Ecol. 40:13-21.

Langhans SD, Tiegs SD, Gessner MO, Tockner K, 2008. Leafdecomposition heterogeneity across a riverine floodplain mosaic. Aquat. Sci. 70:337-346.

Moorhead DL, Sinsabaugh RL, 2006. A theoretical model of litter decay and microbial interaction. Ecol. Monogr. 76:151-174.

Newell SY, 2003. Fungal content and activities in standing-decaying leaf blades of plants of the Georgia Coastal Ecosystems research area. Aquat. Microb. Ecol. 32:95-103.

Olson JS, 1963. Energy storage and the balance of producers and decomposers in ecological systems. Ecology 44:322-331.

Peltoniemi K, Straková P, Fritze H, Iráizoz PA, Pennanen T, Laiho R, 2012. How water-level drawdown modifies litterdecomposing fungal and actinobacterial communities in boreal peatlands. Soil. Biol. Biochem. 51:20-34.

Pettit NE, Davies T, Fellman JB, Grierson PF, Warfe DW, Davies PM, 2012. Leaf litter chemistry, decomposition and assimilation by macroinvertebrates in two tropical streams. Hydrobiologia 680:63-77.

Pozo J, Basaguren A, Elósegui A, Molinero J, Fabre E, Chauvet E, 1998. Afforestation with Eucalyptus globulus and leaf litter decomposition in streams of northern Spain. Hydrobiologia 373/374:101-109.

Sariyildiz T, Anderson JM. 2003. Interactions between litter 
quality, decomposition and soil fertility: a laboratory study. Soil. Biol. Biochem. 35:391-399.

Straková P, Anttila J, Spetz P, Kitunen V, Tapanila T, Laiho R, 2010. Litter quality and its response to water level drawdown in boreal peatlands at plant species and community level. Plant. Soil. 335:501-520.

Sun ZG, Mou XJ, Liu JS, 2012. Effects of flooding regimes on the decomposition and nutrient dynamics of Calamagrostis angustifolia litter in the Sanjiang Plain of China. Environ. Earth Sci. 66:2235-2246.

Torremorell A, Gantes P, 2010. Decomposition and nitrogen dynamics of Rhynchospora asperula in floating soils of Esteros del Iberá, Argentina. Wetl. Ecol. Manag. 18:191-201. Trinder CJ, Johnson D, Artz RR, 2008. Interactions among fungal community structure, litter decomposition and depth of water table in a cutover peatland. Fems. Microbiol. Ecol. 64:33-448.

Wallis E, Raulings E, 2011. Relationship between water regime and hummock-building by Melaleuca ericifolia and Phragmites australis in a brackish wetland. Aquat. Bot. 95:182-188.

Wright EL, Black CR, Cheesman AW, Turner BL, Sjögersten S, 2013. Impact of simulated changes in water table depth on ex situ decomposition of leaf litter from a neotropical peatland. Wetlands 33:217-226.

Wrubleski DA, Murkin HR, Valk AG van der, Nelson JW, 1997. Decomposition of emergent macrophyte roots and rhizomes in a northern prairie marsh. Aquat. Bot. 58:121-134.

Xie YH, Yu D, Ren B, 2004. Effects of nitrogen and phosphorus availability on the decomposition of aquatic plants. Aquat. Bot. 80:29-37. 